\title{
THE SPANISH POPULATION OF CUBA AND PORTO RICO.
}

\author{
By Mr. Charles M. Pepper, \\ Of Washington, D. C.
}

In any discussion of the natives of Cuba and Porto Rico, it is not possible entirely to separate the Latin from the African race. They exist together in those Islands and their future is woven together inseparably. Each race has kept its own identity, yet there has been a reciprocal or a mutual influence. The African has benefited by the tolerance and kindlier consideration, the less pronounced antipathy, of the Spaniard as compared with the Anglo-Saxon. Conversely the Negro has had a steadying influence, if I may so call it, on the Spaniard. I do not mean to say that this has been the result of racial intermixture, but rather that the Negro living side by side with the Latin race has modified the Latin temperament.

It is well to have this knowledge at the outset as it also is well to recognize the status of the Negro. That the advance which has been made may be lost by a disproportionate growth of black population is the spectre of a brooding imagination. Porto Rico has no room for newcomers of the laboring class. The present-day problem there is to find an outlet for an overcrowded population. Cuba can support six times the existing number of inhabitants, but economic and political causes have combined to discourage schemes of Negro colonization, while white immigration from Spain has been in progress for the last two years and is certain to continue. With a perception of these facts it is not nècessary to controvert the presumption of the Caucasians in Cuba and Porto Rico being smothered by a black cloud. There will be no smothering of the African either, but there will 
be a white preponderance large enough to settle the race question.

We may analyze and study the natives of Cuba and Porto Rico who are of Spanish stock with better understanding when we know that in each Island they comprise substantially two-thirds of the inhabitants, a little less in Porto Rico and a little more in Cuba. This is shown in the census compiled under the direction of the War Department by experts. It is a pleasure to refer to a government publication so comprehensive, so well digested and so trustworthy as these volumes. They furnish an example of the value of utilizing trained intelligence.

By this census we find that in Porto Rico out of a total of 953,243 the native-born inhabitants number 939,371 , of whom 578,000 are white and 361,367 colored. In Cuba the proportion is $\mathrm{I}, 067,354$ whites to 505,443 blacks and mulattoes. That means a full million persons of Spanish birth or descent.

"We all know," says Walter Bagehot, "how much a man is apt to be like his ancestors." This observation applies to the natives of both Islands, but with greater force, I think, to those of Cuba. In both instances we may be sure they take after their ancestors from Spain and its adjoining possessions. Nor is the ancestry remote. "Two hundred years," said a chronicler nearly a century ago in describing Porto Rico and her people, " are lost in obscurity." For an understanding of the inhabitants of the present day it is not necessary to grope in darkness seeking to recover those lost pages of history. We know that as in Cuba the Indian race is extinct and that the Indian mixture of which some travelers have discoursed is an imaginary one.

The ancestry of the present generation of Porto Rican natives need not be traced back more than a century and a quarter. Originally the immigration was from the southern part of Spain, Andalusia and Castile having the right to people the Island to the exclusion of the other provinces of 
the Peninsula. Andalusia furnished the larger number and left the stronger impress, but in time the prohibition was raised and the emigrants mingled in one stream, which had its sources in all parts of Spain. Ultimately the stream became a swollen one and the little Island, through immigration and natural increase, had all the inhabitants she could sustain. This happened a good many years ago, so it may be said that the major proportion of the natives of Porto Rico are of Spanish blood two or three generations removed. The result we have to-day is a thin-blooded people, living chiefly on vegetable diet and physically degenerated from their sturdy ancestors. It is an agricultural population, the bulk of which is called peons. The majority of the peons live worse than the field laborers, so far as I have been able to observe, anywhere else in the West Indies. Their dwellings are very small, thatched huts raised two or three feet from the ground and rarely containing more than one room, though sometimes there is a board or a canvas partition. The number of inmates seldom is less than half a dozen and more often is ten or twelve. They are prolific in their poverty. Most of them do not own their huts. These belong to the coffee, tobacco or sugar planters. It is a consequence of the old political conditions, which kept the peons practically as serfs of the soil.

The more general term for the Porto Rico countrymen is gibaros. The name implies a larger degree of personal independence than applies to the peons, for the gibaros often are small land owners. Both peons and gibaros are a peaceful, easygoing people, guileless and trustful. As I have found them they are obliging and hospitable, though the population is too crowded for unstinted hospitality. The observer from the north always calls them lazy. Usually they are pictured by travelers as lolling in hammocks or twanging the gourd guitar while waiting for the bread-fruit, the orange or the cocoanut to drop from the overhanging tree into their mouths. Their amusements are sedentary, 
the cocking main being the chief one because it requires the least exertion. I am not going to lighten the shades of this picture, yet one or two observations may be in point. The indolence of the tropics is inherent. The visitor from the temperate zone who has had previous experience, if he wants to do anything calling for effort is wise enough to do it at once, for as the days pass he has less inclination for exertion, even where pleasure or entertainment is the object. If the reservoirs of energy stored up by the native of the north are so soon exhausted, how much should be expected from a people who must go back fifty, one hundred or one hundred and fifty years for their original storehouse of energy?

During the Spanish rule the government was placed so far above the people of Porto Rico that they are not to be blaned if, in the beginning, they abuse the broader privileges which have come to them under American institutions. Their first tendency was intolerance. When elections were held they applied literally the doctrine that the spoils belong to the victors. Perhaps American politicians would take this as evidence of a highly developed capacity for selfgovernment. They proposed not only to fill the offices with their own friends, but also to make their enemies pay all the taxes. It was simply the rebound from conditions under which they had no part in filling the offices and no share in raising the taxes.

The tendency to political abstractions may be noted as a part of the Latin temperament. An outcropping of it was seen in Porto Rico. When the American Congress remitted two million dollars of revenue to the Island, one enthusiast proposed that the sum should be expended in erecting a magnificent Temple of Justice. The practical American officials spent the money in building roads and schoolhouses.

In Cuba native-born persons, whether white or black, or of foreign parentage, are called Criollos, or Creoles. How- 
ever, in common usage the term more often is applied to the white Cubans, and this means chiefly the inhabitants who are of Spanish descent. In the fierce protests against bad government the line between the Spaniards of to-day-that is those born in the Peninsula and its adjacent Islandsand the Spaniards of yesterday - that is those whose fathers, grandfathers and great-grandfathers were born there-sometimes used to be drawn as if they were alien and antagonistic races. But it does not need a scientific analysis to caution us against mistaking passing and justifiable political passion for racial antipathy when the race is one.

Here I am reminded of what James Anthony Froude, the English historian, said when in his despairing survey of the British West Indies he turned aside to contrast them with the Spanish possessions. "We English," he wrote, "have built in those Islands as if we were but passing visitors wanting only tenements to be occupied for a time. The Spaniards built as they build in Castile and they carried with them their laws, their habits, their institutions and their creed. . . . Whatever the eventual fate of Cuba, the Spanish race has taken root there, and is visibly destined to remain. Spanish, at any rate, they are to the bone and marrow, and Spanish they will continue."

We must go back to Catalonia, Andalusia and the shores of the Mediterranean; to the Canaries and the Balearic Islands; to Asturias, Galicia and the Basque provinces of Spain for the customs, habits, traditions, creed, amusements, language and tendencies of the natives of Cuba. Preferably we should give the most attention to Catalonia, Galicia and Asturias, for it is from these three provinces that the major portion of the later immigration has come.

A certain village in the far interior of Cuba was a hothouse of revolutionary agitation. I visited it at the close of the war when the American military authorities were concerned over the threat of reprisals against the Spaniards. The Cubans professed to hate the whole race and in those 
days when long-restrained passion was finding vent they thought they did hate their own parent stem. They told me the two classes had nothing in common. Yet they had everything in common. The well from which the children were drawing water was of even more ancient origin than Spanish, for it was of the older Moorish construction known as the noria. That day there was a fiesta or church holiday. The baile, or dance, which was a feature of the evening celebration, and which I witnessed, varied only a shade from the representation of the customs of Galicia, which I had seen at the leading Spanish theatre in Havana a few evenings previously. The music was an air which had floated over from the Gulf of Biscay. The entertainment provided me at the posada, or inn, was such as I had read of in the pages of Gil Blas. The houses were like those in an eighteenth century print of Don Quixote. On a later day mass was celebrated by the priest for the repose of the soul of Antonio Maceo and other Cuban insurgents, and the ceremonial was that of the Spanish Church in the middle ages. After seeing these things I did not give much heed to the Cuban's talk that they hated the whole Spanish race. Root and branch were too much alike for the hatred to endure.

Then there is the guajiro, or countryman, seated at the door of his bohio, or palm-thatched cabin, playing his guitar. Usually he is portrayed in his broad straw hat with fringed edges, the front turned in a flap and exposing his honest face while the back slopes down over his neck. The hat is known as the sanjuanero, because of its universal use on the feast day of St. John the Baptist, a popular Spanish holiday. To the accompaniment of the guitar is sung a ballad, called a decima, or a cancion. All this is a characteristicaily Cuban picture. The traveler will see it wherever he goes throughout the Island. Yet it is a Spanish picture, too, and the decimas and canciones, though the subjects are local, are frequently mere repetitions of the provincial songs and ballads heard among the Spanish peasantry. 
Differences are noted in the natives of the different provinces of Cuba, due chiefly to the immigration from which was drawn the original stock. The Spanish strain of blood is preserved in its greatest purity in the central region of Puerto Principe or Canaguiey. Though sparsely settled, three-fourths of the population of this section is white. For half a century the Camagüeyans were the most intense revolutionists. They vindicated their Spanish fighting ancestry by their armed opposition to Spanish government. Their free, open-air life and their isolation from the rest of the Island strengthened their independence of a governing country across the seas, yet they kept unchanged Castilian traditions and usages. Sometimes it has seemed to me that among these people could be traced the Moorish blood and a survival of the customs of Granada. The men are stronger physically and more responsive mentally than in other parts of Cuba, and of the women it has been said that they present the Spanish type slightly modified and perhaps embellished by the soft skies of the tropics. The inland city of Puerto Principe, with its narrow streets and overhanging balconies is a perfect reproduction of many towns in Spain. I have been told by travelers that the houses might be mistakened for those of Seville or Cordova. And it must be said that heretofore the inhabitants of Camaguiey have shown themselves as unprogressive in public improvements, and as strongly opposed to innovations as the old towns of Spain. They have inordinate pride, a true Spanish trait, the mark of ignorance and isolation. This quality is redeemed by their courtesy and hospitality.

We may be asked to believe that all the sturdy qualities of the Spanish peasantry have been lost in the transfusion of the tropics, like a flower that has gone to seed; but while allowance must be made for the modifications of temperament due to climate and environment, I think we will find that the native Cuban of to-day, when the depths of his nature are sounded, is not materially different from his Cas- 
tilian forbear. It has been well said that the peasantry were the secret of Spain's greatness in the past, and perhaps may be the secret of her greatness in the future; a peasantry who were noted for their freedom, independence, endurance and native nobility. In Asturias every toiler was a prince; in Caștile every man was an hidaigo. Says a recent writer in treating of the Spanish people: "Proud, self-respecting dignity; simple, sober habits; native good manners and kindness are the characteristics of all classes of the nation."

How far have these characteristics been changed by transplantation to tropical surroundings? The Spaniard in Cuba still prides himself that he is un hombre serioso, a seriousminded man. As for the native Cubans, during the last four years I have had the opportunity to observe them under all conditions, though more frequently in adversity than in prosperity. The traits described are of an agricultural people, and the Cubans are essentially an agricultural people, and must continue so. Of their hospitality no one who has traveled over the Island can entertain a doubt. It is simple and genuine. No conventional hypocrisy gilds it. It has been said that hospitality wanes as civilization advances. If that be true, whoever has known country life in Cuba will rejoice secretly over the slow advance of a supposedly superior civilization.

Politeness and courtesy go with this hospitality. Then there is an obliging disposition and a goodnature which is one of the defects of character. The Cuban does not like to hurt your feelings by telling you unpleasant truths, so he is apt to agree with you. Though he knows you are wrong and will carry away wrong impressions, he will let you do so rather than contradict you.

Another example of goodnature is seen in the blunted moral sensibility which has come from long training under corrupt government. The Cuban or Spaniard does not fully subscribe to the saying "to rob the state is not to rob." When he knows of some one who is stealing he may remon- 
strate privately with the thief. He even may give a hint of the peculation, yet he shrinks from open denunciation and from the inconvenience which may be caused to himself and to the thief by a public exposure. It is his goodnature that makes him recoil from the penalty of wrongdoing just as it causes him to sanction the wasting of public funds for the benefit of individuals. This goodnature is one of the obstacles to many reforms in government, or measures which appear to American eyes as reforms. To my own mind it always will be a question whether the jury system is a real palladium of liberty among a goodnatured people.

The temperance and sobriety of all classes of the Cuban population are partly due to climatic influences, yet there is a moderation in methods of living and in recreation which is a Spanish inheritance and is not due to climate. It requires an effort on the part of the strenuous American to be temperate in anything, but the Cubans are temperate without effort. Their peaceful disposition is universal. They are not quarrelsome among themselves or with strangers. A darker shade of their character may be found in the revengefulness with which supposed injuries are righted; hence sometimes the ambush, the knife in the dark, even the assassination, and the burning of the sugar planter's cane for revenge.

There is also the duplicity which is employed to foil policies and purposes. Duplicity is the weapon of the weak. Without it revolution against the superior power of Spain never could have succeeded. While it exists among native Cubans to an unpleasant extent it is offset by a high degree of trust in those who gain their goodwill. This is another trait of a people who can be led but not driven. Distrust and suspicion once aroused the sullen characteristics appear. These are one manifestation of passive or moral resistance. They are worthy the study of statesmen, for it was the passive resistance of the Cuban people, the natives of Spanish origin, which thwarted the government of Spain 
in the dying years of the nineteenth century and ended the glorious pageant of colonial history which was ushered in with the discoveries of Columbus.

This positive resistance was illustrated in its highest form during the period of insurrection which was marked by the Weyler reconcentration. There is in the Spanish nature an indifference to physical suffering, of which the Inquisition, the cruelties of the Conquistadores, the extermination of the native Indians, are the black monuments of history. The passive manifestation was seen during the reconcentration, and was seen in heroic aspects, too. Stoic philosophy, inflexible determination were shown by a people conscious of their own doom of extinction, giving their moral support to a revolution which they were too weak to abet physically, and offering a passive opposition to the military measures of the Spanish government which was more potent than could have been an army in the field. When the campesinos, guajiros, or countrymen, endured all this, they were designated as pacificos. The country inhabitants of Cuba to-day rightly might be called pacificos, for with anything like good government they are the most peaceful people in the world.

Often I witnessed this same stoicism or physical endurance among the Spanish soldiers. The recollection of it causes me to smile when the effort is made to draw a fundamental distinction between the native Cubans and their Spanish ancestors. Seeing the peasant lads of Spain bearing the neglect and abuse of their officers with the patience of dumb brutes; watching them die by the thousands from the fevers; observing their distress scarcely less keen than that of the reconcentradoes, I wondered at their failure to mutiny and speculated on the processes which through the centuries had produced this docility, yet the one point always stood out and this was their capacity to sustain suffering. Cuban reconcentrado and Castilian soldier lad alike showed it, but on the part of the soldier it was passive endurance alone, 
while with the mass of the Cuban population it was passive resistance. Moreover, on their side always were some bold leaders among whom the spirit of revolt was active, and with the Negro infusion they kept up an insurrectionary movement which dragged the pacificos, half doubtingly and half sympathetically, after them. Kindred to these qualities of endurance, which perhaps is only one form of fatalism, are others. They are apathy, lethargy, inertia, lack of the initiative faculty.

It may excite surprise to characterize as sentimental a people who in their endurance and their resistance have so many elements of stoicism, yet the Cubans of all classes are sentimental in the highest degree. By sentiment I do not mean merely Latin emotionalism, which is temperamental. With these people there is the deepest affection for their land. No one who has dwelt under its kindly skies, and who has experienced the impressiveness of the palm-tree landscape, can fail to sympathize with that feeling. The sentiment now is seeking for the realization of aspirations and ideals in the symbolism of a Cuban flag. That symbolism the United States is striving to guarantee under the lightest of restrictions and without thwarting the patriotic Cuban aspiration for independence which, however disappointing in its first results, is worthy of respect.

From what has been stated of the characteristics and traits of the natives of Cuba, an idea may be had of the lines along which their development should be sought. It should not be by doing violence to customs, traditions, laws and institutions which have been inherited from their Spanish ancestors, or to sentiments which have sprung from the soil and have become part of their own being. The development of the Cuban people that is to be a homogeneous people is even more a social and industrial problem than a question of political government. Here we are likely to be met with the usual off-hand assumption that the indolence of the tropics bars progress. I think a more correct definition 
of this indolence of the tropics was that given by a Porto Rican author. He called it "the negative inclination to work." When we approach the sociological side we may have repeated to us Mr. Ingersoll's famous word picture of a colony of New England preachers and Yankee schoolma'ams established in the West Indies and the third generation riding bareback on Sunday to the cock fights.

On the industrial side it is the old idea of slave labor and later of coolie labor as the only mechanism which is capable of working under a burning sky. Leaving out the human element in this manner, naturally we must exclude the stimulus and incentive to greater enjoyment and greater comfort in living. I am one of those who, from somewhat limited observation, believe that the negative inclination to work can be turned into a positive disposition to labor. In Hawaii, in Cuba, Porto Rico and other West India Islands it always has seemed to me a question of the management of men rather than of abstract deductions regarding labor in the tropics. That the human energies shall be exerted with the same fierce zeal or the same stustained effort as in the north we do not expect, but sustained effort is not impossible.

Philosophical generalizations in dealing with this subject are so easy that I hesitate to descend from that high plane to the level of concrete instances which may controvert philosophy. Yet here are a few illustrations.

We hardly need be told that in Porto Rico most of the natives go barefoot. An American official who was charged with penitentiary administration was distressed by the idleness of the convicts. He set them to work at various useful occupations. One of these occupations which they learned most readily was making shoes. Few of these convict shoemakers ever had worn foot-leather. When some of those whose sentences were light were released their first move was to seek work in order to earn money with which to buy shoes. The American official did not pretend to be a political economist, but when he got to thinking it 
over he reached the conclusion that the Porto Rican natives would work harder whenever they became possessed with the notion that there was more comfort in wearing shoes than in going barefoot. I think he was right. American contractors who were building bridges, constructing roads and doing other work of that kind, always complained of the laziness of the natives, yet some of them would admit that when they put the incentive of more comfort before the peons or laborers they got better results.

In Havana last winter an electric railway was being constructed and much of the work had to be done under high pressure. It was in charge of a shrewd young American engineer who at one time had 2,700 men under him. Everybody predicted his failure in completing the contract. Everybody was sure that the white and the black Cubans and the Spanish peasants could not be relied on. The engineer did not argue the proposition. He knew human nature and he knew how to select good subordinates. They in their turn knew how to handle men. They urged the laborers by example and they set forth the inducements for hard work. The electric railway was finished on time. The young American told me that the labor capacity of the Havana individual workingman was as high as the labor capacity of the individual workingman in Pittsburg. On that calculation he completed his contract.

Some of us who had known Cuba in the days when the torches of the insurgents and the torches of the Spanish troops were rendering it a charred wilderness, were surprised this season to note everywhere the evidences of recuperation. All the planters were ruined and few of them were able to get the money with which to repiant their estates, yet the sugar crop this year is larger than it has been for six years past. The bankers in Havana and the railway managers all over the Island, knowing the poverty of resources, have been surprised at the extent of the cane planting. Many of them told me that they hardly knew 
how it was done, but that the country people somehow managed to do it. They wanted their homes again and they wanted some of the comforts of life. That was the inducement. An indolent people, without incentive to shake off tropical lethargy, never would have done it. I could give a dozen similar cases in which these Cuban countrymen were aroused from their apathy, but the recital would take too long.

Can we forecast the future from these scattered instances? Probably the philosopher will say no, but I believe Cuban guajiro and the Porto Rican gibaro can be made to want more to eat; to desire a larger cabin with something besides a palm thatching; can develop an ambition to provide for his housewife more kitchen utensils than the single pot or kettle which is hung over the charcoal fire; can be induced to long for straw mattings and chairs for his humble dwelling; to emulate his neighbor in procuring an extra calico dress for his wife and daughters, and something besides a ragged pair of duck or linen trousers and a cheap cotton shirt for himself. In my mind's eye $I$ also see the time when through some neighbor's example he will want to have his children going to the country school, and his pride will cause him to exert himself laboriously so that they may be clothed with more garments than has been the custom in the tropics. These are homely illustrations and may carry no profound truths, yet let this condition of emulation apply to a million people and let the inducements to higher living be set forth, is it certain then that the ease of supplying the bare needs of existence in a warm country will clog all the incentives and the stimulus to labor?

Of what might be called the political traits or the characteristics for self-government I shall have to treat briefly. Something of them may be learned from what has been said of the habits, customs, traditions and environment. For a century only the destructive tendencies of the Cubans could find expression; hence conspiracies, revolts, insurrections 
and active or passive revolution. The great Nation which has most to do with the future development of Cuba and her people, of all perils will beware of arousing their passive resistance. A discerning observer from Spain at the beginning of the last insurrection, told his countrymen that passive resistance was the characteristic of the Island. Does the country produce it? he asked, and then continued. Perhaps it is the climate? Perhaps it is the child of tropical influences? He did not answer his own question of its origin satisfactorily, but he noted that this passive resistance was the hidden rock against which the strongest will and the most resolute purpose were shattered. Let the United States avoid the hidden rock.

While the Cuban character for a century was shown in its destructive tendencies, a final judgment cannot be formed of its constructive and administrative capacity by a trial of two or three years. On the part of any people centuries of the lack of training in political education and of practice in popular and representative government cannot be corrected in the experience of a twelve-months. It is easy to point out the defects and vices of the Spanish nature and their inheritance and modifications in the Cuban character. No great exertion of the intellect is required to sneer at racial weaknesses which are patent and which proclaim themselves. But human progress is not along these lines. It is advanced by appealing to the virtues, not by exploiting the vices of a people. In their present experiment, to realize their aspirations there should be stretched out to the Cubans wot the strong hand, but the helping hand, of the United States.

Following the topic assigned to me, I have sought to confine myself closely to the natives of Spanish blood and their influence in the future of the two West India Islands with which the United States is most intimately concerned. I would not be understood as ignoring the effect of immigration from this country, for there will be an immigration and a commingling of the two peoples. Cuba will be benefited 
by the presence and the example of many Americans who will settle in the Island. Yet for years, the bulk of the arrivals, following the course which is indicated, will be from Spain. This will reinforce the existing two-thirds of the population which is of Spanish stock. It means a reinforcement of the Castilian language, of Spanish traditions, religious faith, customs, manners, habits of thinking and methods of living. In other words it renews and refreshes the Spanish strain among the native Cubans. In all our dealings with the Cuban people this must be kept in mind.

"The luxuriant zone of the tropics," says Humboldt, " offers the strongest resistance to changes in the natural distribution of vegetable forms." The analogy holds in political and social institutions. Tenacious of everything that has been his, the Spaniard transplanted to the tropics acquires greater resistance. Pushed, he becomes stubborn and unyielding. Persuaded, he may be led if too great violence is not done to his convictions. To lead and guide, not to drive, is the American solution of the race problems in the West Indies. 